\title{
ENRAIZAMENTO DE ESTACAS DE KIWIZEIRO COM FITORREGULADORES NAS QUATRO ESTAÇÕES DO ANO
}

\author{
ROOTING OF KIWIFRUIT CUTTINGS WITH GROWTH REGULA TORS IN THE \\ FOUR SEASONS OF THE YEAR
}

\author{
Elisangela da Graça Boeno Paes \\ Orientadora: Profa. Dra. Katia Christina Zuffellato Ribas
}

\begin{abstract}
RESUMO
A propagação de kiwizeiro (Actinidia deliciosa A. Chevallier (C. F. Lang etA. R. Ferguson)) normalmente ocorre pela enxertia das copas sobre porta-enxertos originados de sementes. Tendo em vista o tempo de formação dos porta-enxertos e posterior enxertia, este trabalho surge como uma alternativa para a propagação da espécie, utilizando a estaquia direta das copas como técnica de maior rapidez e eficiência. Diferentes concentrações das auxinas exógenas ácido indol butírico (IBA) e ácido naftaleno acético (NAA) foram aplicadas em solução e em talco, na base de estacas caulinares de kiwizeiro das cultivares Bruno, Abbott e Monty, oriundas de plantas comerciais pertencentes à Fazenda Boutin, localizada em Porto Amazonas-PR, coletadas nas quatro estações do ano (outono/2001, inverno/2001, primavera/2001 e verão/2002). As estacas foram preparadas com comprimento de aproximadamente $12 \mathrm{~cm}$ e diâmetro médio de $0,65 \mathrm{~cm}$ e tiveram suas bases imersas por 10 segundos em soluções concentradas contendo fitorreguladores e nos tratamentos em talco, conforme segue: T1: água destilada; T2: 2500 mg.L-1 IBA (solução); T3: 5000 mg.L-1 IBA(solução); T4: 2500 mg.L-1 NAA (solução); T5: 5000 mg.L-1 NAA (solução); T6: talco inerte; T7: 2500 mg.Kg-1 IBA (talco); T8: 5000 mg.Kg-1 IBA (talco); T9: 2500 mg.Kg-1 NAA (talco); T10: 5000 mg.Kg-1 NAA (talco). Os dados foram analisados dentro de cada estação separadamente segundo um delineamento inteiramente casualizado com arranjo fatorial de 10 tratamentos e 3 cultivares, com 4 repetições por combinação, sendo as unidades experimentais formadas por 10 estacas. As estacas foram mantidas em tubetes utilizando vermiculita como substrato, permanecendo em casa-de-vegetação com nebulização intermitente. As avaliações foram realizadas aos 70 dias da instalação do experimento, sendo observadas as seguintes variáveis: porcentagem de estacas enraizadas; número de raízes por estaca; comprimento das três maiores raízes por estaca; porcentagem de estacas com calos; porcentagem de estacas vivas e porcentagem de estacas mortas. Pelo trabalho foi possível concluir que estacas de kiwizeiro das cultivares Bruno, Abbott e Monty apresentaram heterogeneidade de resposta com relação ao enraizamento nas quatro estações do ano; as estações da primavera e verão apresentaram elevada mortalidade das estacas; as maiores porcentagens de enraizamento foram obtidas com $5000 \mathrm{mg} . \mathrm{Kg}-1 \mathrm{NAA}$ em talco para as cultivares Bruno (70,0\%) e Monty (40,0\%) no inverno e 5000 mg.L-1 NAA em solução para a cultivar Abbott $(37,5 \%)$ no verão.
\end{abstract}

\begin{abstract}
Propagation of the kiwifruit (Actinidia deliciosa A. Chevallier (C. F. Lang et A. R. Ferguson)) usually is done through grafting of crown over rootstocks. Aiming to decrease time for formation of rootstocks followed by grafting, the present appears as an alternative for the species propagation utilizing direct cutting from crown as a technique for faster speed and efficiency. Different concentrations of synthetic auxins, indolebutyric acid (IBA) and naphtaleneacetic acid (NAA), in solution and powder, were applied in the kiwifruit stem cuttings of Bruno, Abbott and Monty cultivars, originated of commercial plants from Boutin's farm, located at Porto Amazonas, PR. They were collected during the four-year seasons (autumnl2001, winter/2001, spring/2001 and summer/2002). The stem cuttings were prepared with approximately $12 \mathrm{~cm}$ length, average diameter of $0,65 \mathrm{~cm}$ being their bases immersed for 10 seconds in the solutions and in powder combinations as follows: T1: distilled water; T2: $2500 \mathrm{mg} \cdot \mathrm{L}^{-1}$ IBA (solution); T3: $5000 \mathrm{mg} . \mathrm{L}^{-1}$ IBA (solution); T4: $2500 \mathrm{mg} \cdot \mathrm{L}^{-1}$

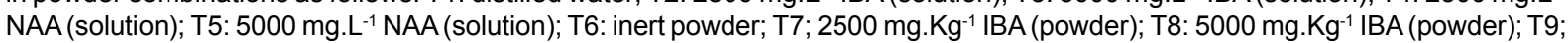
$2500 \mathrm{mg} . \mathrm{Kg}^{-1} \mathrm{NAA}$ (powder); T1O: $5000 \mathrm{mg} \cdot \mathrm{Kg}^{-1} \mathrm{NAA}$ (powder). Data were analyzed within each station separately, according to a complete randomized design with factorial arrangement of 10 treatments over 3 cultivars, with 4 replications per combination, being the experimental units composed of 10 cuttings. Cuttings were planted in plastic containers using vermiculite as growing media and kept in greenhouse with intermittent mist. After 70 days the following variables were observed: rooted stem cutting percentage; number of roots per stem cutting; length of the three bigger roots per stem cutting; callus stem cutting percentage; alive stem cutting and dead stem cutting percentage. Through this work it was possible to conclude that there is heterogeneity of the rooting potential among the studied cultivars; summer and spring showed high death rate; the largest rooting average was obtained with $5000 \mathrm{mg}$. Kg-1 NAA in powder, for Bruno (70,0\%) and Monty (40,0\%) cultivars in winter, and $5000 \mathrm{mg} \mathrm{L-1} \mathrm{NAA} \mathrm{in} \mathrm{solution} \mathrm{for} \mathrm{Abbott} \mathrm{cultivar} \mathrm{(37,0 \% )} \mathrm{in} \mathrm{summer.}$ Key-words: Actinidia deliciosa, cutting, IBA, NAA.
\end{abstract}

